\title{
A TUTELA AMBIENTAL DA PAISAGEM NO DIREITO BRASILEIRO
}

\author{
Ivette Senise Ferreira \\ Profa. Titular de Direito Penal, Medicina Forense e Criminologia e \\ Diretora da Faculdade de Direito da Universidade de São Paulo
}

\begin{abstract}
Resumo:
A autora trata da evolução histórica da proteção da paisagem no País, iniciando seu estudo desde a época do descobrimento. Verifica também sua relação com o valor econômico, razão de sua proteção inicial, e de sua exploração por outros países quando do abandono da Coroa portuguesa. Finaliza com a situação contemporânea, comentando as inovações apresentadas pela Constituição de 1988 e sobre as novas caracterizações da tutela ambiental.
\end{abstract}

\begin{abstract}
:
The author's study is about the historical evolution of the landscape protection in our country. She starts her work from the discovery of Brazil, and analyses the relationship between the landscape protection with its economical value, reason of its beginning and of its exploitation by other countries when Portugal abandoned its intent, and concluded it with an analysis of the contemporary situation, surrounded by the innovations brought by the Constitution of 1988 and the new dimentions accomplished by the environmental protection.
\end{abstract}

Unitermos: patrimônio cultural; atentado contra a paisagem; lei ambiental.

\section{Antecedentes.}

O descobrimento do Brasil costuma ser ilustrado, em muitas de suas narrações, como "a visão do paraíso" a primeira reação dos marinheiros da frota cabralina, após 44 dias entre o mar e o céu, ao avistarem no horizonte uma serra verdejante pontilhada pelo cume de um monte "mui alto e redondo" paisagem que mais parecia uma miragem, apesar da expectativa atribuída a esses navegadores, de que certamente já sabiam o que poderiam esperar.

A narrativa desse achado, feita por Pero Vaz de Caminha em carta enviada ao rei D. Manuel, captou com minúcias os primeiros momentos vividos 
pelos recém-chegados e também descreveu com precisão a terra e os seus habitantes naturais, seus animais, sua vegetação e o seu bom ar. Nesse documento vamos encontrar a primeira referência à paisagem brasileira que, mais tarde, iria encantar a todos os estrangeiros que a visitaram, inspirando, nos nossos dias, o verso, colocado em música, do "país tropical, abençoado por Deus e bonito por natureza"...

Relatava Pero Vaz de Caminha, louvando as belezas naturais da terra descoberta, que "de ponta a ponta, é toda praia, muito chã e muito formosa" acrescentando depois: Águas são muitas, infindas. E em tal maneira é graciosa que, querendo-a aproveitar, dar-se-á nela tudo, por bem das águas que tem" ${ }^{1}$

Não foram porém os valores estéticos da nossa terra, mas sim os interesses econômicos dos conquistadores que inspiraram inicialmente a proteção ambiental dos recursos naturais, expressa nas leis que aqui foram aplicadas quando a colonização começou.

Após o entusiasmo inicial do descobrimento, por três décadas o Brasil havia sido virtualmente abandonado pelos portugueses, mais interessados em conquistar a Índia e em desenvolver as feitorias que haviam instalado na costa africana, que lhes rendia um rendoso comércio. O litoral desguarnecido do País tornou-se então presa fácil dos aventureiros que acorriam ao Novo Mundo em busca de riquezas, com a predominância dos franceses que haviam tomado a dianteira no tráfico lucrativo do pau-brasil, infringindo assim o Tratado de Tordesilhas, que desde 1494 dividira o mundo entre castelhanos e portugueses.

Ficou célebre, e ilustra bem tal fato, na história das nossas origens a captura da nau francesa "Peregrina" pelos portugueses no Mediterrâneo, quando voltava do Brasil carregada com 15 mil toras de pau-brasil, 3 mil peles de onça, 600 papagaios e 1.8 tonelada de algodão, além de outras matérias vegetais e minerais, 0 que motivou Portugal a voltar a sua atenção para a necessidade da colonização do Brasil e da repressão aos invasores, concedendo maior proteção ao seu imenso território.

A preservação dos nossos recursos naturais expressou, pois, primeiramente, uma necessidade de garantir a exclusividade na exploração das nossas riquezas pela Coroa portuguesa, que literalmente saqueou o País desde então, embora tenha promovido uma ocupação mais intensa do território, com o envio de

1. "Carta de Pero Vaz de Caminha" in Os três únicos Testemunhos do Descobrimento do Brasil, org. por Paulo Roberto Percira, Rio de Janeiro, Lacerda Ed., 1999. p. 58. 
muitos colonos e degredados, e alguns donatários, o que deu início à miscigenação com os nativos e propiciou melhor adaptação aos trópicos para os recém-chegados.

Pesquisas históricas na área ambiental apontaram a existência de uma ampla legislação protecionista no Brasil, vigente desde o século XVI, mas extremamente ineficaz, dada a extensão territorial e a ausência de fiscalização, como apontou Ann Helen Wainer, que analisou as normas vigentes nessa matéria a partir do descobrimento. ${ }^{2}$

Assinala a autora que inúmeras normas jurídicas de natureza ambiental foram promulgadas pela Coroa portuguesa, e também pelas autoridades estrangeiras durante os períodos de dominação espanhola e holandesa, nos séculos XVI e XVII, mas todas elas com o intuito de resguardar os interesses financeiros dessas potências nas terras coloniais brasileiras.

As principais preocupações do legislador, nessa fase da nossa história, eram as riquezas florestais, valorizando-se a madeira como um bem indispensável à expansão ultramarina dos navegadores europeus. Com esse objetivo já figurava uma proibição do corte deliberado de árvores frutíferas no Livro $\mathrm{V}$ das Ordenações Afonsinas, a legislação que vigorava em Portugal à época do descobrimento. A partir de 1521, quando foi concluida a compilação das "Ordenações do Senhor Rey Dom Manoel" o mesmo Livro $\mathrm{V}$ detalhou melhor a proteção dos recursos naturais, que se estendeu ao novo território, com diversas normas destinadas a questões referentes a produtos alimentícios, que incluíam a caça de perdizes, lebres e coelhos, a qual foi disciplinada, sendo vedada em alguns lugares, ao mesmo tempo que se proibia o desvio para fora do reino de cavalos, gado, couros e peles, bem como de gêneros alimentícios básicos (Título LXXXVIII), estabelecia-se a proteção das abelhas e suas colméias (Título XCVII), e mantinha-se a incriminação para o corte de árvores frutíferas (Título C), às quais eram atribuídos valores, para efeito de reparação do dano ecológico, sendo aplicável a pena de "degredo para o Brasil" quando a árvore abatida tivesse valor superior a "trinta cruzados" (Título LXXXIII).

Nessa fase, que corresponde à instauração do regime das Capitanias hereditárias no Brasil, a comercialização do pau-brasil foi oficialmente declarada como monopólio real da Coroa portuguesa nas Cartas de doação aos capitães-

2. Wainer, Ann Helen. Legislação Ambiental Brasileira Subsídios para a História do Direito Ambiental. Rio de Janeiro, Ed. Forense, 1991, p. 5. 
donatários, sendo reiterada nos respectivos Forais, onde se estabeleciam os direitos e as obrigações tributárias dos donatários para com o rei de Portugal.

No século XVII, com a substituição das Ordenações Manuelinas por novas compilações, passam a vigorar, no Reino e nas colônias portuguesas, as Ordenações Filipinas, nas quais foram incluídos inúmeros dispositivos relativos à matéria ambiental, incluindo mesmo as primeiras questões urbanísticas. O seu Livro $V$, além de manter as incriminações anteriores, multiplicou a cominação da pena de degredo para o Brasil para os infratores e introduziu novas tipificações, como a da proibição de jogar na água material que pudesse matar os peixes e sua criação, ou sujar as águas dos rios e lagoas (Título LXXXVIII, $\S 7^{\circ}$ ).

No mesmo período, outras disposições protecionistas foram editadas, como as do "Regimento sobre o Pau-Brasil" a primeira lei florestal brasileira, promulgada em 1605. Nela, além da proibição do corte de pau-brasil sem expressa licença real, que sujeitava o infrator à pena de morte e de confiscação de toda a sua fazenda, previam-se os critérios para a concessão de licença para o corte e o seu registro, designava-se a quantidade permitida, que constituiam várias infrações, sujeitas a penas rigorosas, e também proibia-se o fogo nas raízes dos troncos de paubrasil para fazerem-se roças, proibição que foi reiterada, um século depois, no Regimento da Relação da Cidade de São Sebastião do Rio de Janeiro, em 1751.

Fica evidente, a partir de então, a preocupação da Coroa portuguesa com o desmatamento desmedido, conforme se pode observar nas Cartas Régias expedidas, de que são exemplo duas Cartas em que D. Maria I, respectivamente em 1773 e em 1797. ordena ao vice-rei do Brasil e ao capitão do Rio Grande de São Pedro o cuidado na conservação das matas e arvoredos, notadamente as que tivessem árvores de pau-brasil.

No final do século XVII várias normas jurídicas referiram-se às questões ambientais, sempre com esse enfoque de regular as atividades exploratórias para a proteção dos interesses econômicos da Coroa, como bem expressou o Regimento concedido ao governador Roque da Costa Barreto, em 1677. que além de ordenar a vigilância das matas para evitar a falta de madeira, especialmente a utilizada na construção dos navios necessários para a comercialização dos produtos coloniais, determinava cuidados com as plantas novas que então estavam sendo transplantadas da Índia para o Brasil, e recomendava o incremento da exploração das minas de salitre, da pesca de baleias e da extração dos minérios de ouro e prata. 
Essas atividades tiveram notável desenvolvimento no século XVIII, quando o povoamento do Brasil avança pelo interior e as cidades aí se formam e se desenvolvem. Os tributos cobrados na exploração das jazidas, de ouro, prata e diamantes, foram então submetidos a uma legislação extremamente rigorosa, que previa, através do "derrame" a obrigação da população na complementação das quantias devidas, quando a arrecadação não atingisse os montantes determinados.

O desenvolvimento da extração dos minérios proporcionou também o desenvolvimento da pecuária e da agricultura, que produziam os gêneros necessários para abastecer essas regiões, sendo inúmeros os editais que ordenavam, sobretudo em Pernambuco e na Bahia, a plantação de mandioca e de legumes com tal finalidade. Igualmente foram estimuladas, através das leis, a plantação de feijão, milho, arroz de outros gêneros comestíveis, além de se dar incentivos específicos à plantação de amoreiras, pimenteiras, caneleiras, cravos-da-índia e árvores de construção. Como curiosidade, aponta-se nesse período uma representação do desembargador Francisco Nunes da Costa à rainha D. Maria I, acusando a lavoura da mandioca de ser a causa da destruição de bosques e de matas na Bahia...

$\mathrm{O}$ esgotamento dos minérios de ouro e diamantes ocasionou a decadência de sua extração, no final do século XVIII, coincidindo com o predomínio da exploração da borracha na Amazônia, cuja colonização se desenvolvera ao longo do século, culminando com um período áureo no final do século XIX. O Brasil deixara de ser povoado apenas na faixa litorânea e agora era ocupado por pequenos povoados, separados por áreas desérticas, principalmente na região centro-sul, requerendo a expedição de várias normas, destinadas à proteção de outras espécies de madeira que não fossem o pau-brasil, a fim de evitar o desmatamento acelerado pelas necessidades das construções, prevendo-se desde então um possível aniquilamento desses recursos naturais.

Durante todo o século XVIII podem ser encontrados dispositivos legais referentes ao corte de certas madeiras, como a tapinhoã e a peroba, aos cuidados com as queimadas e exportações, e até mesmo determinações aos governadores das capitanias para que protegessem as matas e arvoredos situados perto dos mares ou às margens de rios. A Coroa chegou até a limitar, tendo em vista o bem público, o direito dos proprietários de cortarem essas árvores de modo arbitrário, determinando a sua demarcação e rigorosa fiscalização, tendo sido criado, em 1796, como aponta Euclides da Cunha no seu "Os Sertões" o cargo de "juiz 
conservador das mattas" que tinha a competência de evitar o descaminho das madeiras, aplicar multas e determinar a prisão dos infratores.

No século XIX, com a chegada da família real portuguesa ao Brasil e a instalação da Corte no Rio de Janeiro, produziram-se notáveis transformações na vida e na paisagem brasileiras. A abertura dos portos, promovida pelo visconde de Caiuru, permitia a exportação de toda a produção colonial, com exceção da do paubrasil, mas em compensação propiciava o ingresso de outras culturas, plantas tropicais e especiarias, vindas da Índia, que passaram a ser cultivadas. O estímulo às artes e às ciências, pela família real, a criação de um Jardim Botânico, a fundação de uma Biblioteca Real e de uma Academia Imperial de Belas Artes, a vinda de naturalistas e de uma missão artística francesa, foram certamente responsáveis pelo maior refinamento dos costumes e do gosto de membros da população brasileira, que passava a se interessar pelos valores estéticos e científicos, além dos econômicos.

D. João VI havia criado, por decreto datado de 6 de junho de 1818, o Museu Real do Rio de Janeiro, que mais tarde se transformou no Museu Imperial, quando foi contratado um paisagista, de nome Glaziou, que realizou os trabalhos de embelezamento do Parque da Quinta da Boa Vista, entre os anos de 1866 a 1876, transformando-se depois, já sob a República, em Museu Nacional.

Tanto o interesse pela história natural do País quanto o da descrição das suas belezas naturais foram regiamente documentados pelos cientistas e artistas que nos visitaram, entre os quais os pintores franceses Jean Baptiste Debret e Nicolas Antoine Taunay, com suas memoráveis aquarelas, seus desenhos e pinturas dos nossos cenários, e os cientistas Johann Spix e Friedrich Von Martius, membros de uma missão científica da Áustria e Baviera, que contribuíram, com suas obras sobre a flora e a fauna brasileiras, para o registro e o conhecimento do nosso meio ambiente. Todos eles contribuem para despertar nos europeus o interesse pelas belezas naturais das terras brasileiras e a sua fama de lugar paradisíaco, estimulando o nascimento de interesses preservacionistas, que irão determinar as primeiras instruções para o reflorestamento costeiro, solicitadas por José Bonifácio de Andrada e Silva, no cargo de Intendente Geral das Minas e Metais do Reino. ${ }^{3}$

3. Além de ser notável silvicultor, José Bonifácio de Andrada e Silva, o Patriarca da Independência, escreveu, em 1813, um trabalho intitulado "Memória sobre a necessidade e utilidade do plantio de novos bosques cm Portugal". apelando para uma regulamentação administrativa destinada a conter a devastação da natureza em Portugal, tendo ainda realizado notável trabalho de Direito Comparado ao cotejar as legislações ambientais da época. 
Após a independência do domínio português, com a promulgação de uma Constituição em 1824, e de um Código Criminal em 1830, continua-se a legislar sobre madeiras e florestas, punindo-se o seu corte ilegal como crime e prevendo-se a reparação do dano ecológico na legislação extravagante. A preocupação ambientalista revela-se nas iniciativas de rearborização da floresta da Tijuca por D. Pedro II, tendo sido contratado mais uma vez o paisagista Glaziou para o embelezamento do local.

Com o advento da República, proclamada em 1889, inaugura-se uma nova fase política no País, que passa a ser regido por uma nova Constituição, e um novo Código Penal a partir de 1890 , que todavia nada mencionaram a respeito da proteção ambiental, tanto dos recursos naturais quanto dos bens culturais, o que também aconteceu com o Código Civil, editado em 1916, que revogou expressamente os alvarás, leis, decretos, resoluções, etc., referentes às matérias de Direito Civil por ele reguladas.

Apesar de ter sido esse começo de século uma época de intensa elaboração de uma legislação propriamente nacional em vários domínios, com o surgimento de um novo Estado brasileiro, foi somente com a Constituição de 1934 que surgiram alguns dispositivos ambientalistas, com a primeira menção à proteção das belezas naturais, ao lado daquela dos monumentos de valor histórico, ao se estabelecer para tanto, no seu art. 10, a competência concorrente da União e dos Estados, adotando a mesma orientação já perfilhada pelo primeiro Código Florestal brasileiro, o Decreto n. 23.793, de 23.01.34, que incluíra em sua tutela "as paisagens pitorescas" Ficou assegurada, desde então, a proteção à paisagem e aos valores estéticos dos recursos naturais como bens ambientais integrantes do patrimônio cultural nacional, que ao Estado cumpre fazer respeitar e proteger, evoluindo o seu conceito e a sua tutela até a concepção mais ampla que adquiriu nos nossos dias.

II A proteção dos valores estéticos do patrimônio cultural brasileiro.

A proteção jurídica do meio ambiente hoje, com o conceito extremamente alargado que lhe proporcionou a Constituição Federal, de 1988, e a legislação pertinente, que procuraram estruturar e garantir o direito ao meio ambiente equilibrado e à sadia qualidade de vida como um dos direitos fundamentais da pessoa humana e também de toda a coletividade, coloca em relevo a amplitude do bem jurídico tutelado, que se apresenta como um complexo articulado e harmônico 
de recursos naturais e de valores culturais, integrados na noção de patrimônio ambiental nacional, a ser preservado no interesse desta e das futuras gerações.

De fato, tanto o patrimônio natural, representado por um conjunto diversificado de bens naturais, dos quais a flora e a fauna constituem a expressão mais comum mas não a única, quanto o patrimônio cultural, constituído, segundo dispõe a Constituição Federal no seu art. 216, por bens de natureza material e imaterial portadores de referência à identidade, à ação e à memória dos diferentes grupos formadores da sociedade brasileira, são ambos condição essencial da origem, do desenvolvimento e da sobrevivência dos indivíduos numa determinada sociedade, permitindo-lhes uma estruturação que condiciona e facilita a vida em comum e garante a sobrevivência das gerações vindouras.

Numa e noutra categoria podemos contudo divisar a inclusão de valores estéticos direcionando a instituição de direitos e procedimentos destinados a garantir a gestão do patrimônio ambiental nacional. Tal se dá para a concretização de uma idéia, consubstanciada em vários princípios e documentos internacionais, de que é necessário estabelecer um sistema de proteção da herança cultural e natural de valor universal a fim de se proporcionar aos homens as condições de vida e bemestar adequadas, em ambiente sadio que ele deve sempre conservar e melhorar no interesse da sobrevivência da própria civilização.

As belezas cênicas e as paisagens notáveis passaram a ser referidas na legislação brasileira quer como bens naturais quer como bens culturais, unificandose depois a sua tutela jurídica, hoje perfeitamente consagrada na legislação ambiental em vigor, particularmente na Lei n. 9.605/98 que estabeleceu sanções penais e administrativas derivadas de condutas e atividades lesivas ao meio ambiente.

A essa conjugação já se fazia referência, em 1937, quando o DecretoLei n. 25, que dispôs sobre o patrimônio histórico e artístico nacional para fins de tombamento, definiu-o como "o conjunto de bens móveis e imóveis existentes no país e cuja conservação seja do interesse público, quer pela sua vinculação a fatos memoráveis da História do Brasil, quer por seu excepcional valor arqueológico ou etnográfico, bibliográfico ou artístico" (art. $1^{\circ}$ ). E, a seguir, quando equiparou a esses bens, declarando-os também sujeitos a tombamento, "os monumentos naturais, bem como os sítios e paisagens que importa conservar e proteger pela feição notável com que tenham sido dotados pela natureza ou agenciados pela indústria humana" $\left(\S 2^{\circ}\right)$. 
Tal dispositivo seguia a orientação estabelecida na Carta Constitucional, de 1937. cujo art. 134 dispunha que os atentados cometidos sobre monumentos históricos, artísticos ou naturais, bem como sobre as paisagens ou locais particularmente dotados pela natureza, eram equiparados aos cometidos contra o patrimônio nacional. E reiterava disposição anterior, do Código Florestal da época, o Decreto n. 23.793/34, que estabelecia a tutela jurídica de florestas, sítios, vegetação e paisagens pitorescas.

Ingressando assim na nossa ordem jurídica como bens jurídicos merecedores de tutela, os valores estéticos relativos à paisagem passaram a figurar nas Constituições posteriores como objeto da proteção do Poder Público, vindo a encontrar a sua configuração definitiva na legislação vigente, mercê das ampliação promovida pela Constituição, de 1988, que largamente privilegiou a proteção ambiental.

Não-obstante, toda a legislação constitucional e infraconstitucional das últimas décadas incluiu a paisagem ${ }_{2}$ ou, em última análise, os valores estéticos a ela relativos, no seu âmbito de aplicação, implícitos na noção de meio-ambiente, seja pelos seus aspeclos naturais seja pelos aspectos culturais.

$\mathrm{Na}$ Constituição de 1934, os arts. 10, III, e 148 mencionavam "a proteção às belezas naturais e ao patrimônio histórico e artístico e cultural"; na Carta Constitucional, de 1937, tratava-se da proteção dos monumentos históricos, artísticos e naturais, além de paisagens e locais especialmente dotados pela natureza (art. 134). A Constituição, de 1946, determinava a defesa do patrimônio histórico, cultural e paisagístico, no seu art. 175; os mesmos termos foram repetidos no art. 172 , parágrafo único, da Constituição, de 1967, e no art. 180 da Carta Constitucional, de 1969. A atual Constituição, de 1988, refere-se à "proteção do patrimônio histórico, cultural, artístico, turístico e paisagístico" (art. 24, VII) para estabelecer a competência legislativa concorrente da União, Estados e Distrito Federal. A enumeração decorre da definição de patrimônio cultural estabelecida no seu art. 216, V. que inclui "os conjuntos urbanos e sítios de valor histórico, paisagístico, artístico, arqueológico, paleontológico, ecológico e científico"

Para o aperfeiçoamento conceitual muito concorreu a pressão exercida pelos organismos e documentos internacionais que impulsionaram a elaboração de uma legislação de caráter ambiental no nosso País, a partir da Declaração de Estocolmo, do Congresso da ONU, em 1972. 
Nesse mesmo ano foi assinada pelo Brasil a Convenção Internacional relativa à proteção do patrimônio mundial, cultural e natural, adotada em Paris durante a Conferência Geral da ONU para a Educação, a Ciência e a Cultura, e depois promulgada aqui pelo Decreto n. 80.978, de 12.12.1977.

Considerando que os bens do patrimônio cultural e natural apresentam um interesse excepcional e, portanto, devem ser preservados como elementos do patrimônio mundial da humanidade inteira, essa Convenção Internacional incluiu na noção de patrimônio cultural:

a. os conjuntos: grupos de construções isoladas ou reunidas que, em virtude de sua arquitetura, unidade ou integração na paisagem, tenham um valor universal excepcional do ponto de vista da história, da arte ou da ciência"

b. "os lugares notáveis, obras do homem e da natureza, bem como as zonas, inclusive lugares arqueológicos, que tenham valor universal excepcional, do ponto de vista histórico, estético, etnológico ou antropológico"

Por outro lado, considerou como patrimônio natural:

a. "os monumentos naturais constituídos por formações físicas e biológicas, ou por grupos de tais formações, que tenham valor universal excepcional do ponto de vista estético ou científico"

b. "os lugares notáveis naturais ou as zonas naturais nitidamente delimitadas, que tenham valor universal excepcional do ponto de vista da ciência, da conservação ou da beleza natural"

Nessa mesma ordem de idéias foram criadas, pela Lei n. 6.513, de 20.12.77. destinadas a serem preservadas e valorizadas no sentido cultural e natural, as áreas especiais de interesse turístico e os locais de interesse turístico, considerando o legislador como de interesse turístico, entre os bens de valor cultural e natural que enumera, a serem protegidos por legislação específica, também as paisagens notáveis.

A proteção legal foi depois intensificada com o advento da Lei n. 6.938/81, que instituiu a Política Nacional do Meio Ambiente e os seus mecanismos de aplicação, a qual incluiu na caracterização da poluição, considerada como "a degradação da qualidade ambiental" a referência às atividades que afetem as condições estéticas ou sanitárias do meio ambiente (art. $3^{\circ} \mathrm{III}, \mathrm{d}$ ).

A Constituição Federal, de 1988, entre as suas várias inovações em matéria ambiental, determinou a proteção de certos espaços territoriais, a serem criados por decreto ou por lei em todas as unidades da Federação. São os Parques 
nacionais, estaduais ou municipais, as Estações ecológicas e as Reservas biológicas e outras áreas especialmente protegidas, às vezes por seus atributos estéticos, "sendo a alteração e a supressão permitidas somente através de lei, vedada qualquer utilização que comprometa a integridade dos atributos que justifiquem a sua proteção" (art. 225, §1 ${ }^{\circ}$, III).

$\mathrm{Na}$ área processual a tutela foi consubstanciada na Lei n. $7.347 / 85$, que instituiu a ação civil pública de responsabilidade por danos causados ao meio ambiente, ao consumidor e a bens e direitos de valor artístico, estético, histórico, turístico e paisagístico, sem prejuizo da ação popular, também cabível. Esta, segundo o disposto na Lei n. 4.717/65, com a nova redação que lhe deu a Lei n. 6.513/77. já incluía na conceituação de patrimônio público, para fins de sua tutela, os bens e direitos de valor econômico, artístico, estético, histórico ou turístico, pelo que passou a incidir também sobre os atos lesivos ao patrimônio cultural brasileiro, parte integrante do patrimônio ambiental nacional. Essa finalidade depois ficou expressa na Constituição Federal, de 1988, cujo art. $5^{\circ}$ LXXIII, dispõe que qualquer cidadão é parte legítima para propor ação popular que vise anular ato lesivo ao patrimônio público ou de entidade de que o Estado participe, à moralidade administrativa, ao meio ambiente e ao patrimônio histórico e cultural, ficando o autor, salvo comprovada má-fé, isento de custas judiciais $e$ do ônus da sucumbência"

Todavia apesar disso, conforme assinala Vladimir Passos de Freitas, a ação popular não vem sendo utilizada na defesa do meio ambiente, pois a ação civil pública já se consagrou como a via mais apropriada para tal fim, uma vez que elimina as dificuldades encontradas pelos litigantes individuais (" $A$ Constituição Federal e a Efetividade das Normas Ambientais" RT, SP 2000, p. 40).

É importante ainda observar que a Constituição Federal atribuiu competência comum da União, dos Estados, do Distrito Federal e dos Municípios para "proteger os documentos, as obras e outros bens de valor histórico, artístico e cultural, os monumentos, as paisagens naturais notáveis e os sítios arqueológicos" (art. 23, III), e, por outro lado, competência concorrente da União, dos Estados e do Distrito Federal para legislar sobre "a proteção ao patrimônio histórico, cultural, turístico e paisagístico" (art. 24, VII), e sobre "a responsabilidade por dano ao meio ambiente, ao consumidor, a bens e direitos de valor artístico, estético, histórico, turístico e paisagístico" (art. 24, VIII). A competência subsidiária dos Municípios é 
afirmada no inciso IX do art. 30 para "promover a proteção do patrimônio históricocultural local, observada a legislação e a ação fiscalizadora federal e estadual"

Nesse particular tem sido entendimento da doutrina que alguns princípios devem ser observados para a definição da competência material, respeitando-se as competências privativas existentes e a ocorrência ou não de interesse nacional, regional ou local, cabendo ao Município lhe maior alcance.

III Os atentados contra a paisagem e as belezas naturais.

O Código Penal de 1940 ao tipificar o delito de dano, no capítulo Dos Crimes contra o Patrimônio, reservou duas figuras penais para a proteção do patrimônio cultural, sob o nomen iuris de dano em coisa de valor artístico, arqueológico ou histórico, no art. 165, e de alteração de local especialmente protegido, no art. 166. Na verdade são elas subespécies do dano no seu tipo fundamental, o do art. 163, às quais o legislador quis emprestar maior realce, diferenciando a sua punição, em virtude do relevante valor dos bens jurídicos atingidos.

A orientação adotada no Direito Penal coaduna-se com doutrina atual, expressa nas normas constitucionais que nos regem, que atribui à propriedade uma função social, que obsta o exercício do direito correspondente se for contrário ao interesse coletivo.

As inúmeras restrições criadas, no sentido de vinculá-lo ao bonum commune omnium, representam, no entender de Nelson Hungria, autênticas "servidões legais" Segundo ele, "em todo o mundo civilizado, a partir principalmente do começo deste século, operou-se um crescente movimento de opinião no sentido da especial tutela de tais bens, cuja preservação atende ao interesse geral da educação e do culto às coisas belas. Até mesmo um interesse econômico coletivo se reconhece na espécie, pois a curiosidade ou atração provocada pelas obras de arte, antigüidades e belezas naturais, fomenta em cada país, e internacionalmente, o pródigo turismo" 4

O crime do art. 165 somente se diferencia do tipo fundamental de dano por referir-se a coisa tombada pelo seu valor histórico, arqueológico ou histórico, pois consiste em: "Destruir, inutilizar ou deteriorar coisa tombada pela autoridade

4. Hungria, Nelson. Comentários ao Código Penal, v. VII. $1^{\text {a }}$ ed., Rio de Janeiro, Ed. Forense. 1955, p. 110. 
competente em virtude de valor artístico, arqueológico ou histórico" E no que se refere ao art. 166, a conduta prevista destina-se a proteger coisas que merecem ser conservadas, mas pelas suas características de beleza, subentendidos os valores estéticos na fórmula adotada que é "alterar, sem licença da autoridade competente, o aspecto de local especialmente protegido por lei" Trata-se aqui, evidentemente, de bens necessariamente imóveis, sendo indiferente que a sua beleza seja produto da natureza ou resulte da interferência do homem, desde que se trate de local colocado sob especial proteção em virtude de lei.

Apesar dessa conotação patrimonial relativa a bens imóveis, por ter sido incluído entre os crimes patrimoniais do Código penal, os tribunais, à falta de outra opção, não hesitaram em aplicar o art. 166 para a simples proteção da paisagem, como se pode verificar no Acórdão JC 60/278, do Tribunal de Justiça de Santa Catarina, que conclui pela caracterização da infração "quando o agente, desautorizado pela autoridade competente e desrespeitando norma legal que protegia local tombado pela Municipalidade, in casu, dunas, degenera e desfigura a paisagem, através da remoção de areia, terraplanagem, colocação de britas e construção de barraco. (JC 60/278).

Todavia é inquestionável que esses dois artigos mencionados, do Código Penal, de 1940, foram tacitamente revogados pela Lei n. 9.605/98, a Nova Lei Ambiental, que contém disposições mais amplas sobre a mesma matéria, no capítulo Dos Crimes contra o Ordenamento Urbano e o Patrimônio Cultural.

IV A proteção da paisagem na atual Lei ambiental.

A Nova Lei Ambiental, Lei n. 9.605/98, tendo introduzido um capítulo especial dedicado aos Crimes contra o Ordenamento Urbano e o Patrimônio Cultural, fez uma ampla revisão da matéria, conservando, com algumas modificações, os tipos penais existentes anteriormente e acrescentando outros, numa tentativa de dar mais eficiência à tutela dos bens culturais, que deixava muito a desejar.

A referência feita à paisagem como bem ambiental nas Constituições brasileiras certamente havia inspirado o legislador, de 1940, a criar no Código Penal, de forma inovadora, a figura da "alteração de local especialmente protegido" prevista no seu art. 166, hoje revogado pelas disposições mais amplas da Lei $n$. 9.605, de 12 de fevereiro de 1998. 
Embora inspirado no Código Penal italiano, de 1930, o dispositivo do Código Penal brasileiro não pudera aproveitar-se do modelo inserido no seu congênere como contravenção penal pela Lei n. 1.497 de 29 de junho de 1939, que introduziu no art. 734 daquele Código o tipo penal "destruição ou deturpação das belezas naturais de lugares sujeitos a especial proteção da autoridade" fazendo menção expressa à qualidade estética do bem jurídico protegido.

No Direito italiano é ele considerado um tipo penal aberto, em que a conduta do agente tanto pode ser comissiva quanto omissiva, dolosa ou culposa, sendo suficiente que se altere de qualquer modo a visão panorâmica, ou melhor dizendo estética, oferecida pela natureza, que pode configurar-se até mesmo mediante a ocultação total ou parcial do panorama em questão. A Corte de Cassação italiana, num processo relativo a ocultação de paisagem da Ilha de Ischia mediante a colocação de cartazes publicitários num anel rodoviário, dispôs que "há alteração de belezas naturais quando por obra humana, que se insere num quadro natural de beleza de conjunto, vem a turbar-se a sensação de gozo estético que a vista oferecia antes da ocorrência do ato lesivo à sua integridade." (n. 1.795, em 21.11.1973). Constitui também orientação jurisprudencial o entendimento de que a beleza paisagística é o resultado de componentes variados, entre os quais a conformação do terreno, a vegetação natural, a distribuição, o tipo e a localização das edificações ou acidentes geográficos existentes, o seu contorno, etc. Assim, a infração pode configurar-se pelo simples nivelamento ou desbarrancamento do terreno, ou mesmo pela destruição da sua vegetação.

O legislador brasileiro preferiu falar em alteração de local, ao invés de limitar-se à alteração das belezas naturais, dando maior amplitude à proteção legal, que foi oferecida também à paisagem urbana, compreendendo os conjuntos de edificações, ou outras obras acrescentadas pelo homem à natureza, que apresentem valor artístico ou cultural, além de estético. Isso, aliás, ficou bem claro na redação que the deu a nova Lei dos crimes ambientais (Lei n. 9.605/98, art. 63), que aprimorou o dispositivo dando-lhe um alcance antes inexistente, pois incluiu a proteção decorrente de decisão judicial, alem da legal e administrativa, objetivando a manutenção da integridade do local, onde se incluem os sítios paisagísticos naturais, e das edificações, onde se presume a paisagem urbana de especial interesse, seja ou não bem tombado, quando não houver autorização da autoridade competente ou estiver em desacordo com a concedida. Constitui o delito a ação de "alterar $o$ aspecto ou estrutura de edificação ou local especialmente protegido por lei, ato 
administrativo ou decisão judicial, em razão de seu valor paisagístico, ecológico, turístico, artístico, histórico, cultural, religioso, arqueológico, etnográfico ou monumental, sem autorização da autoridade competente ou em desacordo com a concedida"

A pena é agora mais gravosa, de reclusão de 1 a 3 anos e multa, mais condizente com a gravidade da conduta lesiva e com as conseqüências que pode provocar no bem jurídico, sendo porém passível de substituição por pena restritiva de direitos, conforme o disposto no art. $7^{\circ}$ desse diploma legal. A ação pode ser cometida por pessoa jurídica, que será responsabilizada segundo as regras dos arts. 21 e 22, sendo de todo conveniente que a pena restritiva de direitos que vier a ser aplicada guarde relação com a falta cometida, orientando-se a punição para a recuperação ou refazimento das áreas ou locais alterados pela ação lesiva.

A redação do dispositivo deixa bem claro que a proibição contida na norma é aplicável à paisagem urbana, além da paisagem natural, no que tange ao seu aspecto, isto é, à visão que delas se tenha ou se possa ter, abrangendo assim a modificação da estrutura das edificações, desde que especialmente protegidas por lei, que pode ser municipal. O Município constitui a instância mais apropriada para a definição da proteção a ser concedida ao bem jurídico em questão, mas somente pode atuar em caráter supletivo, quando a matéria for de interesse comum e nãoexista ação federal ou estadual dirigida a essa tutela; deve porém atuar privativamente quando a matéria for do interesse exclusivo local.

Em conseqüência, podemos encontrar a tutela jurídica da paisagem e dos valores estéticos que ela pressupõe, nos três níveis de legislação: federal, estadual e municipal (como é o caso, por exemplo, da Lei federal n. 6.513/77. que dispõe sobre a criação de Áreas Especiais e de Locais de Interesse Turístico; da Lei estadual de São Paulo, n. 6.884/62, que dispõe sobre parques e florestas estaduais e os monumentos naturais; da Lei Orgânica do Município de Osasco, etc.).

Essa tutela tem sido reconhecida como necessária por todos aqueles que comungam do interesse da preservação ambiental, sob todas as suas formas, como pressuposto de uma sociedade mais harmônica e mais justa. Assim se manifestaram os subscritores da Carta de Goiânia, que consubstanciou as conclusões do V Congresso Internacional de Direito Agrário, realizado naquela cidade em 1990, que concluiu pela necessidade de se proceder ao adequado manejo dos recursos naturais renováveis em todas as suas manifestações, aí incluindo as paisagens. 
Procurando intensificar e melhor equacionar outros aspectos dessa tutela, a Lei ambiental inclui duas inovações, nos seus arts. 64 e 65, que cuidam respectivamente da construção irregular e da poluição visual constituída pela pichação e pela grafitagem, que alteram e enfeiam a paisagem urbana.

A construção irregular, que anteriormente era considerada mera infração administrativa, passivel de embargo ou demolição, é agora incriminada, considerando-se que o interesse social e o bem comum devem prevalecer sobre os interesses individuais. Nesse sentido, dispõe o art. 64 da Lei n. 9.605/98:

Promover construção em solo não edificável, ou no seu entorno, assim considerado em razão do seu valor paisagístico, ecológico, artístico, turístico, cultural, religioso, arqueológico, etnográfico ou monumental, sem autorização da autoridade competente ou em desacordo com a concedida: Pena detenção de seis meses a um ano, e multa"

Como se vê, com essa tipificação não se protege apenas a paisagem e os valores estéticos do local, mas também os valores ecológicos, como as florestas de preservação permanente criadas pela Lei n. 4.771/65 (Código Florestal), e depois transformadas em reservas ou estações ecológicas pela Lei n. 6.938/81; e também os valores artísticos, referidos no Decreto-Lei n. 25/37 ou turísticos, de acordo com a Lei n. 6.513/77; ou ainda por seu valor monumental, que tem o significado de "locais de rara beleza" os chamados "monumentos naturais"

O infrator responderá pelo crime praticado, sem prejuízo da ação administrativa competente, ou, eventualmente, da reparação do ilícito civil.

Essa tipificação, na verdade, vem ao encontro de incontáveis reclamaçōes contra o crescimento desordenado de aglomerações urbanas situadas em locais inapropriados, ou de preservação ambiental, como são as fontes, represas e cursos d'água, e também contra o aniquilamento das áreas verdes e das paisagens notáveis, que agora se procura evitar. A questão é particularmente grave nas cidades litorâneas e serranas, que constituem, pela sua beleza, importantes pólos de turismo, sendo prejudicados pela ganância de aproveitadores agindo en nome de um duvidoso progresso...

Objeto material do delito é o solo não edificável e seu entorno que não podem receber construções a não ser em situações excepcionais, quando haverá autorização da autoridade competente, como, por exemplo, no caso de construção de moradia para um diretor de Parque Nacional, etc. Mesmo nesses casos, lembra Gilberto Passos de Freitas, "a construção, o material, as cores, tudo será feito em 
harmonia com o local. O mesmo se dá com o entorno, ou seja, o espaço físico necessário à harmonização entre o local protegido e a área que o circunda" ${ }^{5}$

A pena cominada ao delito é baixa, detenção de 6 meses a 1 ano, cumulativa com a multa, constituindo, pois, uma infração de menor potencial ofensivo, submetendo-se as regras da Lei n. 9.099/95, que permite a transação e outras vantagens.

A outra inovação da Lei ambiental tipifica uma conduta que se tem tornado o tormento dos moradores das cidades em geral e, particularmente, dos grandes centros urbanos, que é a pichação desmedida de paredes e locais em geral, em total infringência aos direitos de propriedade e aos valores estéticos que mesmo nos centros urbanos merecem respeito e preservação. Nesse sentido, dispõe o art. 65:

Pichar, grafitar ou por outro meio conspurcar edificação ou monumento urbano: Pena detenção de três meses a um ano, e multa.

Parágrafo único. Se o ato for realizado em monumento ou coisa tombada em virtude do seu valor artístico, arqueológico ou histórico, a pena é de seis meses a um ano de detenção, e multa'

Não-obstante as considerações que podem ser feitas sobre as características dos autores dessas ações nos grandes centros urbanos na época moderna, se trata evidentemente de um atentado significativo à paisagem urbana ou à estética das cidades que, do ponto de vista jurídico, deve ser considerado como semelhante à alteração de paisagem, já analisada, incidindo pois nas regras estabelecidas para a tutela ambiental.

Apesar da existência de sanções administrativas, ou civis, nos casos em que a reparação do dano causado for possível, a legislação extrapenal revelou-se insuficiente para coibir as condutas abusivas que se tornaram cada vez mais freqüentes, além de audaciosas, pois atingem o alto dos edifícios e lugares considerados inacessíveis, e às vezes até mesmo bairros inteiros, como acontece na periferia de São Paulo.

O Direito Penal procura assim coibir essa prática anti-social com a tipificação do art. 65 da Lei ambiental, o qual abrange não-somente a pichação e a grafitagem mas também outros modos de conspurcação que, em última análise, revelem a finalidade de sujar o objeto que se quer atingir, mas sujar de maneira a

5. Freitas, Vladimir e Gilberto Passos de. Crimes contra a Natureza, $6^{a}$ ed., São Paulo, Ed. Revista dos Tribunais, 2.000, p. 207. 
macular, a manchar, a cobrir de imundície a coisa visada, de tal forma que a intervenção penal se apresente como necessária e relevante para a proteção do bem jurídico, no intuito de resguardar a influência que o meio ambiente limpo e bem cuidado tem sobre o bem-estar das pessoas em geral.

Tratando-se todavia de infração de pequeno potencial ofensivo, esses atos incidirão nas normas da Lei n. 9.099/95, podendo ser objeto de transação, segundo o seu art. 76.

Devemos observar que a prestação de serviços à comunidade, com a reparação do objeto danificado pelo infrator, apresenta-se como a retribuição mais apropriada para essa conduta abusiva, pelo seu caráter educativo, que é o que se procura imprimir nessa espécie de medida alternativa para a pena de prisão, e deveria ser por isso largamente aplicada.

De qualquer forma, em todas a figuras penais aqui assinaladas, relativas à proteção do ordenamento urbano e patrimônio cultural, a tipificação é feita somente na sua forma dolosa. O que significa que é necessário apurar-se a existência da vontade livre e consciente do agente na execução da conduta descrita, e a finalidade de atentar contra os valores estéticos que justificam a intervenção da lei penal em defesa da paisagem, até que a idéia da sua conservação penetre fundo na cultura de nosso povo, de tal forma que essas normas protecionistas se tornem desnecessárias.

São Paulo, julho de 2000. 